УДК 377/378:37.091.217(4-11)

https://doi.org/10.32835/2223-5752.2018.16.175-182.

\title{
ОСОБЛИВОСТІ ФІНАНСУВАННЯ ПРОФЕСІЙНОЇ ОСВІТИ В КРАЇНАХ СХІДНОЇ ЄВРОПИ
}

Олександр Радкевич,

кандидат юридичних наук,стариий науковий співробітник лабораторії

зарубіжних систем професійної освіти і навчання

Інституту професійно-технічної освіти НАПН України

ORCID ID: 0000-0002-2648-5726

Researcher ID: E-9146-2016

mr.radkevich@gmail.com

КЛЮЧОВІ СЛОВА:

фінансування,

професійна освіта,

самоврядування,

навчальні програми,

служби зайнятості,

неформальна освіта.
Реферат

У статті розкрито децентралізований характер управління закладами професійної освіти в країнах Східної Європи у контексті підвищення відповідальності органів місцевого самоврядування щодо планування та управління, зміцнення зв'язків між закладами професійної освіти та соціально-економічним середовищем. Приділено увагу участі місцевих та регіональних громад щодо покриття поточних витрат студентів та капітальних видатків.

Встановлено, що фінансування закладів професійної освіти забезпечується бюджетами держав, місцевими й регіональними органами влади, а також окремими особами та роботодавцями, що являє собою змішане фінансування. Урядом визначається базова вартість кожного календарного року. Означено, що професійні заклади освіти мають право змінювати або доповнювати конкретні навчальні програми в межах профінансованої групи освітніх програм (визначених стандартом професійної освіти і навчання) та формою навчання. 3'ясовано, що податкова система не заохочує роботодавців інвестувати в професійне навчання. Відтак, тільки великі стабільні підприємства можуть дозволити собі навчальний бюджет для своїх працівників. Досліджено, що вартість підготовки одного кваліфікованого робітника в Литві включає асигнування на заробітну плату персоналу й соціальне страхування, підвищення кваліфікації педагогічних працівників та фінансування на придбання різних навчальних ресурсів, проведення практичних занять.

Приділено увагу вивченню діяльності місцевих (локальних) служб зайнятості (бірж праці), котрі зобов'язуються виплачувати закладам професійної освіти кошти в межах вартості ваучера за підготовку/ перепідготовку осіб. Проаналізовано двосторонні договори про професійну підготовку між безробітним і місцевими службами зайнятості і тристоронні трудові договори (між безробітним, місцевими службами зайнятості (біржами праці) та роботодавцями).
Постановка проблеми. У зв'язку із запровадженням політики децентралізації та передачі повноважень на місця, заклади професійної освіти України були передані 3 державної форми фінансування на фінансування з обласних (регіональних) бюджетів відповідно до їх територіального розташування. 3 огляду на це, важливим є огляд сучасних підходів до фінансування професійної освіти, що застосовуються в країнах Східної Свропи.

Аналіз наукових праць. Особливості професійної підготовки учнівської молоді шляхом організації профільного та дуального професійного навчання в контексті євроінтеграційних процесів обгрунтовано В. Радкевич $(2017 ; 2018)$. Окрему увагу приділено інноваційним формам фінансування професійного навчання учнівської молоді в країнах Європейського Союзу (ЄС) у дослідженнях С. Леу (О.Бородієнко та ін., 2017; Л.Пуховська та ін., 2015).

Мета статті. Розкриваючи проблематику фінансування професійної освіти в країнах Східної Європи, важливим є огляд прогресивних освітніх політик, видів та способів фінансування у Греції, Естонії, Латвії, Литві та Словенії.

Виклад основного матеріалу. У Греції, починаючи 32001 р., фінансування закладів професійної освіти носить децентралізований характер. Головною метою такої фінансової політики $\epsilon$ підвищення відповідальності органів місцевого самоврядування за якість планування та управління закладами освіти, зміцнення зв'язків між ними та соціальноекономічним середовищем. Фінансування закладів професійної освіти у Греції є змішаним, оскільки забезпечується бюджетами держави, місцевих та регіональних органів влади, а також 
окремими особами та роботодавцями. Більшість фінансів розподіляються державними органами, які спрямовують свої зусилля на короткі курси для безробітних, дорослих або зайнятих працівників, котрі хочуть змінити сферу діяльності в рамках заходів щодо залучення непрацюючого населення на ринок праці.

Фінанси державного бюджету - це заробітна плата для викладачів та інших працівників галузі освіти; підвищення кваліфікації викладачів та інших фахівців; додаткове фінансування освіти для груп ризику (етнічні меншини, учні 3 особливими потребами) та для обдарованих учнів; транспортні витрати; навчальні матеріали й обладнання; інфраструктура та програмне забезпечення для інформаційнокомунікаційних технологій; фінансування на розвиток бібліотечних фондів; капітальні вкладення (будівлі, інфраструктура) тощо. Місцеві та регіональні уряди також покривають певні витрати: утримання шкільних приміщень, обслуговування обладнання; експлуатаційні витрати; транспортні витрати для перевезення учнів; харчування та проживання у студентських гуртожитках; капітальні видатки, відповідно до критеріїв, визначених Міністерством освіти Греції (Athanasouli, 2015). Якщо місцеві/ регіональні уряди не в силах забезпечити мінімальне фінансування, залучається централізований Фонд вирівнювання, спрямований компенсувати розмір дефіциту коштів. Місцеві органи влади, як засновники та власники закладів професійної освіти, також можуть бути інвесторами стосовно будівель/ інфраструктури (Gechert \& Rannerberg, 2015). Крім того, компаніям компенсовуються кошти, витрачені ними на навчальні програми для свого персоналу (OECD, 2016). Контроль за цим здійснюється організацією зайнятості та трудової сили, до якої надходять відомості від організації соціального забезпечення про внески роботодавців (кожна компанія сплачує $0,45 \%$ від валової заробітної плати працівника за рік). На основі цього значна кількість компаній отримує фінансові стимули для залучення до навчання студентів, випускників програм професійної освіти. Також існують субсидії для компаній, які беруть участь у різних заходах 3 професійного навчання та консультування. Ця діяльність фінансується Європейським соціальним фондом, що сприяє навчально-виховній роботі відповідно до міжнародної системи акредитації програм (EPAS), підвищення якості навчання та розвитку закладів професійної освіти (SEK), як це передбачено новим Законом «Про середню освіту» (Закон 4186/2013) (Athanasouli, 2016).

У Греції реалізуються також програми реформування професійної освіти та підвищення кваліфікації на період 2016-2020 pр. Одразу зосередимо увагу на тому, що виконання цих програм напряму залежить від зовнішнього фінансування, зокрема, з Свропейського Союзу. Так, економіка Греції в 2017 р. зросла на 1,4\%, що вперше з 2007 р. свідчить про зростання ВВП, який перевищив $1 \%$. Очікується, що відновлення економіки прискориться при успішному завершенні програми підтримки стабільності в Греції, а рівень безробіття зменшиться на $20 \%$ до 2019 р. завдяки програмам професійної підготовки непрацюючого населення. У зв'язку 3 цим, були створені стимули для співпраці підприємців та закладів професійної освіти. Наприклад, Закон «Про навчання упродовж усього життя» (Закон 3879/2010, ст. 18) (Calleja \& Dorn, 2014) встановлює стимули для постійного розвитку людських ресурсів країни, наприклад, призначення субсидій для закладів професійної освіти, що здійснюють безперервне професійне навчання. Звернемо також увагу на те, що у зв'язку 3 істотними суспільно-економічними змінами в країні, здійснюється переоцінка послуг, що фінансуються з державного бюджету. Очікується, що ці послуги так само будуть оцінені/переоцінені закладами професійної освіти (професійна підготовка та освіта дорослих) i отримуватимуть фінансування відповідно до їхньої ефективності.

B Eстоніï формальна професійна освіта і навчання, загалом, фінансується державою. У 2016/17 pр. 99\% професійних навчальних закладів перебували в державних програмах фінансування. Приватні заклади професійної освіти також можуть подати заявку на державне фінансування, якщо будуть відповідати установленим державою вимогам. У 2016/17 pр. базова вартість програми на одного учня на рік (60 кредитів) складала 1,665 євро, помножена на коефіцієнт (від 1,0 до 4,0) в залежності від групи навчальних програм, форми навчання та особливих потреб учнів. Витрати включають заробітну плату персоналу, навчальні матеріали та технічне обслуговування (наприклад, опалення та електроенергію). Уряд визначає базову вартість кожного календарного року. Цей механізм фінансування застосовується до всіх рівнів та форм професійної освіти i 
навчання. Щороку міністр освіти визначає кількість студентів, які будуть фінансуватися 3 державного бюджету впродовж наступних трьох років за групою навчальних програм та переліком навчальних закладів (наприклад, «медіа-технології», що включає навчальні програми від «мультимедіа», «технологія друку» та «фотографія»). Показники оновлюються щороку впродовж наступних двох років. Заклади професійної освіти мають право змінювати/ доповнювати конкретні навчальні програми в межах профінансованої групи освітніх програм (визначених стандартом професійної освіти і навчання) та формою навчання. Якщо заклад професійної освіти і навчання не має достатньої кількості учнів у групі, фінансування може бути використане для іншої групи навчальних програм або для продовження професійної освіти і навчання в тій же групі навчальних програм. Декілька програм професійної підготовки, що фінансуються 3 приватних джерел фінансування, доступні в державних та муніципальних закладах професійної освіти. Такі програми зазвичай користуються великим попитом, але не є частиною державних програм. Державні та муніципальні заклади професійної освіти можуть також надавати платні послуги 3 професійної підготовки дорослого населення без обмеження віку. Вони також можуть залучати додаткове фінансування з інших джерел, таких, як міжнародні проекти. Відомо, що загальні витрати на професійну освіту i навчання скоротилися в країні з 129 млн. євро в 2010 р. до 108,7 млн. євро у 2014 р. через скорочення інвестицій в інфраструктуру та обладнання, оскільки в цей період були завершені великі інвестиційні проекти. Важливо наголосити, що 66\% загальних витрат держави на професійну освіту і навчання спрямовується на заробітну плату персоналу

$\boldsymbol{y}$ Латвіi процедури фінансування професійної освіти визначаються Законами «Про освіту» та «Професійну освіту», відповідно до яких освітні установи фінансуються 3 державного бюджету, бюджету місцевих громад або приватного сектора (табл. 1). Витрати державного бюджету на програми професійної освіти розраховуються на одного студента. У Латвії досить обмежені інструменти державної підтримки й заохочення працівників до навчання. Фінансові ресурси роботодавців здебільшого використовуються для навчання дорослого населення країни. Однак, зауважимо, що податкова система не заохочує роботодавців інвестувати у професійне навчання. Відтак, тільки великі, стабільні підприємства можуть сформувати спеціальний бюджет для навчання своїх працівників. Ці підприємства зазвичай мають стратегію розвитку людських ресурсів. Малі підприємства менше інвестують у навчання працівників, оскільки в їхніх планах превалюють завдання виживання на ринку. В останні роки спостерігається посилення тенденції до використання програм ЄС, інших закордонних фінансових інструментів та приватних фондів для фінансування різних проектів, що ви користовуються в сфері професійної освіти, неформального навчання та інших освітніх програм для дорослого населення.

\section{Джерела фінансування професійної освіти у Латвії}

Таблиця 1.

(Daija and Kinta, 2016)

\begin{tabular}{|l|l|l|l|}
\hline Школи & Зарплата викладача & Фіксовані витрати * & Нефіксовані витрати ** \\
\hline Держава & Державний бюджет & Державний бюджет & Державний бюджет \\
\hline Місцевий уряд & Державний бюджет & $\begin{array}{l}\text { Бюджет місцевого } \\
\text { самоврядування чи } \\
\text { державний бюджет }\end{array}$ & $\begin{array}{l}\text { Бюджет місцевого } \\
\text { самоврядування чи } \\
\text { державний бюджет } \\
\text { (за винятком окладу } \\
\text { вчителя) }\end{array}$ \\
\hline Приватний сектор & $\begin{array}{l}\text { Приватне } \\
\text { фінансування / } \\
\text { державний бюджет }\end{array}$ & $\begin{array}{l}\text { Приватне } \\
\text { фінансування }\end{array}$ & Приватне фінансування \\
\hline
\end{tabular}


* послуги, енергія, вода, обладнання тощо;

** стипендії, обслуговування гуртожитків, громадське харчування, практичні заняття, страхування, культура, освіта та спорт, зарплата (крім вищої професійної освіти).

Заробітна плата вчителів державних та місцевих закладів професійної освіти сплачується 3 державного бюджету. Органи місцевого самоврядування можуть додатково асигнувати фінансові ресурси в заробітну плату викладачів закладів професійної освіти. Для приватних професійних закладів, що реалізують акредитовані програми базової, середньої та вищої освіти, включаючи професійну підготовку, держава також може фінансувати заробітну плату викладачів. Більшість закладів професійної освіти є державними та комунальними; отже, національний бюджет це основне джерело фінансування професійної освіти. Органи місцевого самоврядування та приватні організації також можуть надавати субсидії. Заклади освіти (як професійні, так і загальні) отримують додаткове фінансування 3 пожертвувань та платних послуг, які можуть використовуватися для придбання навчальних посібників та обладнання, стипендій і (частково) для покриття витрат. Додатковим джерелом фінансування професійної освіти $є$ плата за навчання. Послуги державних $\mathrm{i}$ місцевих закладів професійної освіти, які здійснюють базову та середню освіту, $є$ безкоштовними. Наприклад, фіксовані та нефіксовані витрати, визначені Кабінетом Міністрів Латвії в 2007 p., це - стипендії; обслуговування студентського місця проживання; послуги 3 реабілітації та харчування для студентів 3 особливими потребами; культурна освіта та спортивна діяльність; практичне навчання на підприємствах; страхування від нещасного випадку на практиці на підприємствах.

У вищих професійних навчальних закладах держава покриває видатки за певну кількість навчальних місць для студентів із задовільними оцінками. Зі студентів, які мають незадовільні навчальні досягненнями, або 3 бажаючих зареєструватися в несубсидованій сфері навчання (з надлишком студентів / випускників) може стягуватися плата за навчання. Органи місцевого самоврядування можуть брати плату в муніципальних спортивних та музичнопрофесійних школах. Заклади професійної освіти можуть одночасно здійснювати освітні програми, що фінансуються з різних джерел, відповідно до Закону «Про освіту» (Professional Master's Study...). Освіта дорослих може фінансуватися за рахунок державних і місцевих бюджетів, ресурсів роботодавців, студентських зборів, пожертвувань та інших джерел. Деякі місцеві органи влади виділяють фіксований відсоток 3 їх бюджету на освіту дорослого населення.

Важливими джерелами фінансування $\epsilon$ інструменти фінансової допомоги $\mathrm{CC}$, включаючи структурні фонди та програми Erasmus+ (колишня програма безперервного навчання упродовж 2007-2013 рp.), які допомогли створити більше можливостей для навчання дорослим через різні проекти. Національний збір даних про фінансування професійної освіти був припинений у 2005 р. Інформація доступна лише для фінансування 3 Європейського соціального фонду, державного бюджету та частково 3 фондів місцевого самоврядування. Згідно з даними, зібраними Міністерством освіти і науки (2013р.), органи місцевого самоврядування виділили майже 2,25 млн. євро на неформальну освіту 63000 дорослих, порівняно, з 1,29 млн. євро на 29000 дорослих у 2009 р. Обсяги підтримки залежать від регіону та місцевого самоврядування.

Національні (державні) установи підтримують проекти розвитку навичок, які фінансуються 3 коштів ЄС. Агентство 3 інвестицій та розвитку (Latvijas Investīciju un attīstības aǵentūra (Investment ...) координує реалізацію проектів із розвитку людських ресурсів, у яких підприємства дуже зацікавлені. Асоціація жінок-підприємців в частині охорони здоров'я координує навчальні заходи для безробітних (у тому числі тих, хто перебуває під ризиком безробіття). Це запроваджено відповідно до плану освіти дорослих, ухваленого Кабінетом Міністрів (2016) (Daija \& Kinta, 2016), який координуватиме процес навчання і здійснюватиме загальний контроль його якості. Органи місцевого самоврядування розробили додаткові інструменти підтримки: фінансування або співфінансування місцевих професійних навчальних закладів (центрів для дорослих, народних шкіл, центрів культури, загальноосвітніх навчальних закладів), які пропонуютьдоросломунаселеннюнеформальне навчання; надання інфраструктури або знижок на оренду приміщень для закладів освіти, котрі здійснюють неформальну освіту дорослого населення; співфінансування проектів СС та 
інших, спрямованих на розвиток неформальної освіти дорослих; надання субсидійгромадським організаціям для забезпечення доступності освітніх послуг.

У Литві фінансування закладів професійної освіти здійснюється 3 державного бюджету. Витрати на практичну складову професійної підготовки розраховуються на одного учня. Методика розрахунку витрат на навчання полягає у визначенні рівня прямих фінансових затрат, котрі необхідні для навчання та професійної підготовки кожного учня, який зараховується до навчальної програми на одну академічну годину. Вартість підготовки одного кваліфікованого робітника включає асигнування на заробітну плату персоналу та соціальне страхування, підвищення кваліфікації педагогів та фінансування на придбання різних навчальних ресурсів, включаючи практичні заняття. Останнє обчислюється за допомогою коефіцієнта, який змінюється залежно від специфіки програми, що задіяні у професійній підготовці. Фінансування закладів професійної освіти розраховується на основі фактичної кількості учнів, помноженої на кількість годин для комплексного виконання програми та витрати на годину навчання.

Вартість навчання для учнів 3 особливими потребами (інклюзія) визначається окремо.

Серед джерел фінансування (табл. 2), внесок $з$ державного бюджету на професійну освіту становить близько $80 \%$ загального фінансування. Частка фінансування від міжнародних організацій залежить від наявності європейських фондів. Крім того, заклади професійної освіти, за затвердженою державною інвестиційною програмою на відповідний рік, можуть отримувати фінансування 3 державного бюджету на будівництво, оновлення (реконструкцію) закладів освіти тощо. Такі витрати можуть також підтримуватися 3 інших фондів, включаючи структурні фонди ЄС. Заклади професійної освіти також отримують доходи від фізичних та юридичних осіб за надані послуги (наприклад, навчальні курси, оренда приміщень тощо). Цей дохід може використовуватись винятково для освітніх цілей та професійного навчання. Для фінансування навчання працівників у приватному секторі використовуються фонди ЄС та видатки підприємств.

Таблиця 2

\section{Фінансування закладів професійної освіти у Литві (\%)} (Statistic...)

\begin{tabular}{|l|c|c|c|c|}
\hline Джерело фінансування & 2010 & 2013 & 2014 & 2015 \\
\hline Державний бюджет & 84,4 & 72,4 & 75,1 & 82,2 \\
\hline Приватні організації & 7,0 & 6,8 & 7,1 & 9,2 \\
\hline Міжнародні організації & 8,6 & 20,8 & 17,8 & 8,6 \\
\hline
\end{tabular}

Підтримка від європейських структурних фондів 2014-2020 рр. має бути спрямована на кілька заходів із розвитку людських ресурсів. Наприклад, за програмою «Компетентний ваучер» (Kvalifikacijų...) 56.8 млн. євро будуть спрямовані на фінансування навчання майже 42 тис. працівників. Проекти планується здійснити в 2017-2023 рр. Інший показник - «Інвестиції в людські ресурси, Литва», спрямований на підтримку навчання працівників іноземних компаній, які працюють у Литві. Загалом, 11.6 мільйонів євро було виділено європейськими структурними фондами для фінансування різнопланових заходів у професійній освіті та іiі розвитку; 49 проектів уже розпочато у 2016 р. і триватимуть вони до 2023 р. Загалом, підприємства фінансуватимуть усі проекти, але по-різному: малі підприємства надаватимуть внески розміром 30\% від загальної вартості навчання, середні $-40 \%$, великі $-50 \%$.

Розглядаючи фінансування закладів професійної освіти щодо підготовки кваліфікованих робітників, неможливо обійти питання навчання безробітних. Так, витрати на професійну освіту для безробітних в основному покриваються за рахунок 
підтримки Європейського соціального фонду. Починаючи з 2012 р., Міністерство соціального забезпечення та праці запровадило систему ваучерів для фінансування такого навчання. Навчальний ваучер - це документ, виданий безробітним державною службою зайнятості - литовською біржею праці (Lietuvos darbo birža...). Місцеві служби зайнятості (місцеві біржі праці) зобов'язуються виплачувати закладу професійної освіти кошти за кожен ваучер, отриманий закладом для надання освітніх послуг за узгодженою програмою професійної підготовки. Безробітний може вибирати заклад професійної освіти зі списку, опублікованому на веб-сайті державної служби зайнятості (біржі праці).

Наразі існує два типи договорів, що можуть бути підписані під час організації навчання для безробітних:

- двосторонній договір про професійну підготовку між безробітним та місцевою службою зайнятості. При двосторонньому договорі безробітний звертається до програми професійної підготовки. Зауважимо, що такі програми формуються відповідно до прогнозів ринку праці та потреб роботодавців. Після навчання безробітний зобов'язується працювати на посаді, запропонованій місцевою службою зайнятості (біржою праці), щонайменше шість місяців, або розпочати власну справу;

- тристоронній трудовий договір (між безробітним, місцевими службами зайнятості та роботодавцями). При тристоронньому договорі програма професійного навчання та заклад професійної освіти погоджується 3 роботодавцем у частині його потреб. Після тренінгу роботодавець зобов'язується найняти безробітного не менше, ніж на шість місяців. Якщо фактичні витрати на навчання перевищують межі, встановлені Урядом, різниця покривається учнем або роботодавцем. Ті ж самі процедури застосовуються до навчання осіб, яких було звільнено.

У Словенії фінансування вищих середніх професійних навчальних закладів на вищих професійних програмах передбачено Законом «Про організацію та фінансування освіти» (Zakon o organizaciji...). Джерела фінансування визначаються метою, обов'язками та відповідальністю, а також наявними умовами фінансування й забезпечення якості освіти. Фінансування для гімназій і вищих професійних закладів розраховується на підставі критеріїв і стандартів, виданих Міністерством освіти. На цій підставі обчислюються кошти з розрахунку на одного студента. Загальний рівень фінансування зазначається у фінансовій угоді, підписаній Міністерством освіти та закладом професійної освіти за кожний бюджетний рік. Обсяг фінансування визначається за допомогою двох методів: по-перше, це стандартизація діяльності та моніторинг фактичних витрат у закладах професійної освіти (як основа для розрахунку); по-друге, це - одноразова (цілісна) фінансова асигнація для професійної освіти. Інші можливі джерела фінансування закладів професійної освіти включають: державні кошти; кошти, внесені засновником(ами) установи; внески галузевих асоціацій та палат; прямі внески роботодавців для надання практики; платежі та збори від студентів, учнів і дорослих; кошти від продажу послуг і продуктів; пожертвування, спонсорство та інші джерела.

Державні витрати, що виділяються на формальну освіту, включаючи професійну освіту, в 2014 р. склали 1991 млн. євро або 5,3\% ВВП. Найбільша частка загальних державних видатків на формальну освіту була спрямована на базову освіту $(43,32 \%)$, значно менше на дошкільну $(18,71 \%)$, середню $(18,13 \%)$ та вищу (19,76\%) (Brenk, 2015). Дорослим у системі професійної освіти й підготовки необхідно самостійно оплачувати курси. Для інших учнів освіта - безкоштовна. У зв'язку iз неповною зайнятістю вони беруть участь у формальних програмах отримання дипломної освіти (середня та вища освіта). Доросле населення має ті ж права, що й студенти денної форми навчання, доти, доки вони не досягнуть 26-річного віку (якщо вони не безробітні й не зареєстровані як шукачі роботи у Службі зайнятості Словенії).

Висновки. Аналіз джерел фінансування професійної освіти у країнах Східної Свропи (Греція, Естонія, Латвія, Литва, Словенія) дає змогу стверджувати, що здебільшого професійна освіта розвивається завдяки фінансуванню 3 державного бюджету та дотаціям з приватного сектора на підготовку кваліфікованих робітників. Встановлено, що в цих країнах відсоток ВВП на освіту в декілька разів вищий за аналогічний в Україні. Професійна освіта в цих країнах $€$ децентралізованою й тому має багато 
альтернативних джерел фінансування (кошти, внесені засновником(-ами) установи; внески галузевих асоціацій та палат; прямі внески роботодавців для надання практики; платежі та збори від студентів, учнів і дорослих; кошти від продажу послуг та продуктів; пожертвування, спонсорство та інші джерела фінансування тощо.). Заслуговує на увагу система державноприватного контролю за прозорістю та ефективністю фінансування професійної освіти.

Позитивним для України є також стимулювання соціального партнерства підприємців та закладів професійної освіти, зокрема, в частині програм професійної підготовки, що фінансуються 3 приватних джерел фінансування, доступні в державних та муніципальних закладах професійної освіти. Такі програми зазвичай користуються великим попитом, але не є частиною державних програм. Зауважимо, що освітні послуги надаються у межах формальної та неформальної професійної освіти.

\section{Література}

1. Радкевич, В.О., 2017. Професійна освіта i навчання: європейський контекст розвитку. Науковий вісник Інституту професійнотехнічної освіти НАПН Украӥни. Професійна педагогіка, 14, с.5-14.

2. Радкевич, В.О., 2018. Науковометодичний супровід модернізації вітчизняної системи професійної та фахової передвищої освіти у контексті євроінтеграційних процесів. Науковий вісник Інституту професійнотехнічної освіти НАПН Украӥни. Професійна педагогіка, 15, с.5-15.

3. Бородієнко, О.В., Пуховська, Л.П., Радкевич, О.П. та Леу, С.О., 2017. Дорожня карта професійної освіти і навчання в країнах Свропейського Союзу. Науковий вісник Інституту професійно-технічної освіти НАПН Украӥни. Професійна педагогіка, 13, c. $123-131$.

4. Пуховська, Л.П., Ворначев, А.О. та Леу, С.О., 2015. Механізми фінансування професійної освіти і навчання в країнах Європейського союзу. В: Л.П. Пуховська, А.О. Ворначев та С.О. Леу. Професійний розвиток персоналупідприємств украӥнах Європейського Союзу. К.: ІПТО НАПН України.

5. Athanasouli, A., Georgiadis, N., Karnemidou, A. and Mavris, D., 2016. Vocational education and training in Europe - Greece. Cedefop ReferNet VET in Europe reports. [online] Available at: $<$ http://libserver.cedefop.europa.eu/ vetelib/2016/2016_CR_GR.pdf $>$ [Accessed 15 October 2018].

6. Gechert, S. and Rannerberg A., 2015. The Costs of Greece's Fiscal Consolidation, Vierteljahrshefte zur Wirtschaftsforschung. Duncker \& Humblot. 84, Iss. 3, pp. 47-59,

7. Calleja, J.J. and Dorn B., 2014. Vocational education and training in Greece Short description,
Luxembourg: Publications Office of the European Union. [online] Available at: <http://www. cedefop.europa.eu/files/4130_en.pdf $>$ [Accessed 15 October 2018].

8. OECD, 2016. Greece in Education at a Glance. [online] <https://read.oecd-ilibrary.org/ education/education-at-a-glance-2016/greece eag-2016-57-en\#page7> [Accessed 14 October $2018]$.

9. Daija, Z. and Kinta, G., 2016. Vocational education and training in Europe - Latvia. Cedefop ReferNet VET in Europe reports. [online] Available at: <http://libserver.cedefop.europa.eu/ vetelib/2016/2016_CR_LV.pdf $>$ [Accessed 15 October 2018].

10. Professional Master's Study Programme TEACHER.Sub-programme: Secondary Education English Teacher. [online] Available at: <https:// www.lu.lv/eng/istudents/degree/study/secondaryeducation-english-teacher $>$ [Accessed 14 October $2018]$.

11. Investment and Development Agency of Latvia (LIAA). [online] Available at: $<$ http://www. liaa.gov.lv $>$ [Accessed 14 October 2018].

12. Statistic Luithuania, 2016. [online] Available at: <https://www.stat.gov.lt/en> [Accessed 14 October 2018].

13. Kvalifikaciju ir profesinio mokymo pletros centras, 2016. Vocational education and training in Europe - Lithuania. Cedefop ReferNet VET in Europe reports. [online] Available at: <http:// libserver.cedefop.europa.eu/vetelib/2016/2016_ CR_LT.pdf $>$ [Accessed 14 October 2018].

14.1Lietuvos darbo birža (Lithuanian Labour Exchange). [online] Available at: <https:// www.ldb.1t/en/Information/Pages/default.aspx $>$ [Accessed 14 October 2018].

15. Zakon o organizaciji in financiranju vzgoje in izobraževanja (ZOFVI). [online] 
Available at: <http://pisrs.si/Pis.web/ Expenditure on formal education. [online] pregledPredpisa?id=ZAKO445> [Accessed 14 Available at: <https://www.acs.si/en/projects/ October 2018].

16. Brenk, E. 2015. Info Mosaic, Slovenian October 2018]. Institute for Adult Education (SIAE), SURS:

\section{KEY WORDS:}

funding, vocational education and training (VET), self-government, curricula, employment services, informal education
Abstract

\section{VET financing specifics in Eastern European countries}

Oleksandr Radkevych

PhD in Law

Senior research fellow

of the Laboratory for foreign VET systems

of the Institute of vocational education and training of the NAES of Ukraine

The decentralized nature of VET schools management in the context of raising the responsibility of local self-government bodies regarding planning and management, strengthening the links between VET institutions and socio-economic environment is revealed. The attention is paid to local and regional governments participation in covering costs for students' current expenditure and capital expenditures.

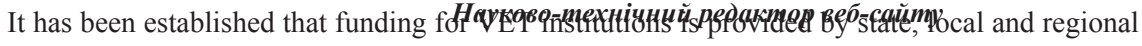
authorities budgets as well as by individuals and employers, which is a mixed financing. The government defines the annual base cost. It is stated that VET schools have the right to modify/ supplement specific curricula within the framework of a funded group of educational programs (defined by VET standard) and training form. It is emphasized that the tax system does not encourage employers to invest in VET. Therefore, only large, stable enterprises can afford a training budget for their employees.

It is investigated that in Lithuania the cost a skilled worker's training includes wage allocation for staff and social insurance, teacher training and funding, and the purchase of various training resources, including practical classes.

The attention is paid to local (local) employment services (labour exchanges) obliged to pay to VET institutions for providing VET services (training re-training) within the cost of a voucher. The attention is paid to bilateral agreements on VET between the unemployed and local employment services and a tripartite labour contract (between the unemployed, local employment services (labour exchanges) and employers).

\section{References}

1. Radkevych, V.O., 2017. Profesiina osvita Radkevych, O.P. ta Leu, S.O., 2017. Dorozhnia i navchannia: yevropeiskyi kontekst rozvytku. karta profesiinoi osvity i navchannia $\mathrm{v}$ krainakh Naukovyi visnyk Instytutu profesiino-tekhnichnoi Yevropeiskoho Soiuzu. Naukovyi visnyk Instytutu osvity NAPN Ukrainy. Profesiina pedahohika, 14, profesiino-tekhnichnoi osvity NAPN Ukrainy. s.5-14.

2. Radkevych, V.O., 2018. Naukovometodychnyi suprovid modernizatsii vitchyznianoi systemy profesiinoi ta fakhovoi peredvyshchoi osvity u konteksti yevrointehratsiinykh protsesiv. Naukovyi visnyk Instytutu profesiino-tekhnichnoi osvity NAPN Ukrainy. Profesiina pedahohika, 15, s.5-15. profesiino-tekhnichnoi osvity NAPN
Profesiina pedahohika, 13, s. 123-131.

4. Pukhovska, L.P., Vornachev, A.O. ta Leu, S.O. 2015. Mekhanizmy finansuvannia profesiinoi osvity i navchannia $\mathrm{v}$ krainakh Yevropeiskoho soiuzu. V: L. P. Pukhovska, A. O. Vornachev ta S. O. Leu. Profesiinyi rozvytok personalu pidpryiemstv $u$ krainakh Yevropeiskoho Soiuzu. K.: IPTO NAPN
3. Borodiienko,
O.V., Pukhovska,
L.P., Ukrainy. 